\title{
Estimating the bioenergy potential of Pinus radiata plantations in Chile
}

\author{
Eduardo Acuña, Miguel Espinosa, Jorge Cancino, Rafael Rubilar, and \\ Fernando Muñoz \\ Laboratorio Biomasa y Bioenergía, Facultad de Ciencias Forestales, Universidad de Concepción, Casilla \\ 160-C, Correo 3, Ciudad Universitaria, Concepción, Chile.
}

\begin{abstract}
E. Acuña, M. Espinosa, J. Cancino, R. Rubilar, and F. Muñoz. 2010. Estimating the bioenergy potential of Pinus radiata plantations in Chile. Cien. Inv. Agr. 37(1): 93102. The bioenergy potential for electricity and ethanol production of Pinus radiata D. Don plantations in Chile was modeled, on a regional basis, using radiata pine plantations areas by age class. Wood basic density equations based on age and growing region, wood moisture content variability, and the efficiency of a hypothetical power plant were used to estimate the amount of electricity produced by biomass at harvesting age including logging residues. Bioethanol yield was estimated at $275 \mathrm{~L} \mathrm{t}^{-1}$ of dry biomass. The uncertainty of the bioenergy production were analyzed using probabilistic distribution functions and an estimate of 1.83 million ha ${ }^{-1}$ of radiata pine plantations by year 2030. Parameters considered for the uncertainty analyses included the rotation age, mean annual increment, annual planting rate, logging residue production by harvesting age, and power plant efficiency. Simulations were projected for 20 years (2010-2030). The results of our model suggest that biomass of logging residues and bolewood of radiata pine plantations would produce 294.8 PJ by 2008, which would cover $83.4 \%$ of the current installed capacity of the Chile Power Central Interconnected System, and could increase to four times the 2008 estimate (381\%) by 2030. Model predictions suggest that bioethanol produced using biomass residues could supply 15 to $25 \%$ of gasoline blends at $2 \%$ (E98) and 5\% (E95), respectively, by year 2010. Bolewood biomass could supply $76 \%$ and $190 \%$.
\end{abstract}

Key words: Bioenergy, bioethanol, biomass, radiata pine, logging residues, Monte Carlo simulation.

\section{Introduction}

Concerns about energy security, environmental care, and economic development have generated increasing interest in the search for alternative sources of fuel (Jun et al., 2009). Forest biomass

Received 14 April 2009. Accepted 10 August 2009. Corresponding author: edacuna@udec.cl is an alternative source of energy because it is renewable and abundant and may reduce emissions of greenhouse gases (Solomon et al., 2007; USDE, 2006; Hamelinck et al., 2005). Cellulose and hemicellulose, the main compounds of forest biomass, are composed of sugars rich in energy that may be transformed into bioethanol by hydrolysis and fermentation (Smeets et al., 2007; USDE, 2006). Biomass may also be used as a raw material to generate electricity and replace fossil fuels. 
In developing countries, firewood is the main source of energy for cooking and heating, although in several places, thousands of people suffer from severe reductions in the firewood supply due to the effects of tree felling and desertification (Chaturverdia, 2004). On the other hand, the use of biomass, especially from forests, as a source of energy has always been an alternative in developing countries (Chaturvedia, 2004). Specific advantages are that i) logging biomass is a renewable and a clean source of energy $\left(\mathrm{CO}_{2}\right.$ emissions are lower than fossil fuels); ii) in several countries where fossil fuels are scarce, bioenergy from wood may increase energetic independence, protecting the national economy from collapses and price problems during international crises; iii) income obtained from the primary production of firewood and alternative sources of energy at local communities may reduce migration from rural communities to urban centers, which will improve local economies; and iv) the development and use of logging biomass as source of energy might create new employment opportunities in the production of biomass for bioenergy generation.

The use of woody species as a source of energy for heating and electric production is a common practice in several developed economies (Smeets et al., 2007). The extensive existing plantation area in Chile, as well as the possibility of increasing the range of productive options, may provide an opportunity to diminish the energetic dependence of the country. The energetic needs of several countries, including Chile, are almost completely satisfied by imported fossil fuels. Although there is general recognition of the positive contribution of renewable energy to diminishing the effects of greenhouse gases, there is a lack of economic incentives to develop this source of energy (Chaturvedia, 2004). Biomass from forest plantations might reduce the increasing fuel requirements for energy and, at the same time, diminish the effects of global warming in three different ways: i) by maintaining the existing carbon supplies (e.g., avoiding the degradation of forests or deforestation); ii) by increasing carbon reservoirs, such as by planting on uncovered lands, increasing the rotation age in plantations, and intensifying the use of biomass in long-term products or constructions; and iii) by sustainably producing biofuels.

Forest biomass can be obtained directly from management of forest plantations (pruning and thinning) or mainly from harvesting residues (Perlack et al., 2005), including stumps. However, this material is often left on the field, placed in piles, or burned for accessibility. Due to the pressure to develop forms of renewable energy, there is currently great interest in using this material to generate bioenergy. A significant number of studies have evaluated the potential uses of forest biomass for fuel, electricity and heat generation (Seiffert et al., 2009; Solomon et al., 2007; CEC, 2001; Graf and Koehler, 2000; Giampietro et al., 1997).

Electricity (bioelectricity) and liquid fuels (biofuels) have been widely analyzed for development at a commercial scale due to the increasing capacity for processing biomass and the increasing residential and industrial demands (Solomon et al., 2007; Gan and Smith, 2006; Cook and Beyea, 2000). Plants that generate electricity from biomass work similarly to plants that consume fossil fuels. However, unlike fossil fuels, biomass is directly burned in boilers to produce high-pressure steam that moves a turbine, which is alternately connected to an electric generator (NREL, 2006). Electric plants that generate renewable electricity commonly supply useful steam, heat and combined heat and energy.

Biofuels are liquid or gas fuels produced from raw materials based on biomass. Bioethanol, biodiesel, biogas, and hydrogen are some examples of biofuels. Bioethanol and hydrogen are produced through the microbial fermentation of sugars, starches, and cellulosic materials. Biodiesel is produced by combining alcohol (generally methanol) with vegetable oil, animal fat, or recycled kitchen oil. Biogas is produced from the anaerobic digestion of volatile organic matter. Bioethanol is the most common biofuel produced from cellulose and hemicellulose (NREL, 2006). Bioethanol has been the center of political discussions in the United States because it was classified as an important alternative fuel that will replace $30 \%$ of gasoline by 
2030 (USDE, 2006). The current technology, which is based on the pretreatment of diluted acid and fermentation, produces up to 80 gallons of bioethanol per dry ton of lignocellulosic biomass (Hamelinck et al., 2005). Sixty billion gallons of cellulosic bioethanol a year are necessary to accomplish this goal, which would require a supply of one billion dry tons of lignocellulosic biomass (Perlack et al., 2005).

In Chile, biomass for energy production may not only come from existing plantations but also from plantations established for this purpose (e.g., short rotation crops for bioenergy production). Nevertheless, the large area of Pinus radiata D. Don plantations $(1,438,383$ ha) (INFOR, 2007), with a harvest rate of around 40,000 ha and an annual management of another 30,000 ha (INFOR, 2007), may be an important source for part of the energetic requirements of the country.

The objective of this work was to determine the potential biomass production from commercial forests and harvesting residues of radiata pine plantations from 2010 to 2030 to produce energy, electricity and bioethanol.

\section{Materials and methods}

\section{Model description}

The biomass from radiata pine plantations was estimated using the planted surface area by class age and administrative region. The plantations were divided into 15 administrative regions, from Valparaíso $\left(33^{\circ} \mathrm{S}\right)$ to Los Lagos $\left(41^{\circ} \mathrm{S}\right)$ (Table 1). For each year of the forecasted period, stemwood biomass was estimated as the product of the plantation's mean annual increment (MAI), the area planted by age class, and coefficients to transform the timber weight into the harvest residue (Equation 1). The MAI, rotation age and coefficients used to estimate the residue from stemwood biomass were assumed to be constant for each region. The wood basic density $\left(\mathrm{kgm}^{-3}\right)$ for each age class was specific for each region.

$$
\operatorname{Bio}_{k}=\operatorname{rcMAI} \sum_{i=1}^{R} \sum_{j=1}^{E_{i}} e_{i j} d_{i j} s_{k i j}
$$

Table 1. Area of Pinus radiata plantations in Chile by age class and region as of December 2006.

\begin{tabular}{lccccccccc}
\hline & \multicolumn{1}{c}{ Surface (ha) by age class } \\
Regions ${ }^{1}$ & 0 & $1-5$ & $6-10$ & $11-15$ & $16-20$ & $21-25$ & $26-30$ & $>31$ & Total \\
\hline Valparaíso & 422 & 2,302 & 1,518 & 2,763 & 1,204 & 1,031 & 385 & 890 & 10,515 \\
Libertador B. O’Higgins & 3,348 & 18,311 & 15,166 & 11,658 & 8,332 & 5,146 & 1,467 & 1,660 & 65,088 \\
Maule & 14,569 & 95,755 & 89,406 & 69,601 & 66,819 & 29,993 & 5,796 & 1,566 & 373,505 \\
Bio Bio & 37,275 & 135,083 & 155,583 & 107,030 & 99,517 & 65,620 & 11,476 & 3,630 & 615,214 \\
Araucanía & 7,145 & 46,695 & 54,090 & 71,939 & 47,498 & 25,274 & 3,339 & 1,561 & 257,540 \\
Lagos & 3,310 & 13,919 & 19,591 & 29,627 & 29,942 & 16,766 & 2,187 & 1,179 & 116,521 \\
Total & 66,068 & 312,065 & 335,354 & 292,620 & 253,311 & 143,830 & 24,650 & 10,486 & $1,438,383$ \\
\hline
\end{tabular}

${ }^{1}$ Administrative regions of Chile. Data was recorded annually by the Servicio Forestal del Estado (INFOR, 2007).

In Equation (1), $\mathrm{Bio}_{k}$ is the amount of stemwood biomass and harvesting residue contained in plantations in the $k$-th year of the projection $\left(\mathrm{M}_{\mathrm{t}}\right), r c$ are the coefficients of harvest residue per unit of biomass harvested $\left(\mathrm{t}^{-1}\right)$, MAI is the mean annual increment of radiata pine plantations for each region $\left(\mathrm{m}^{3} \mathrm{ha}^{-1} \mathrm{year}^{-1}\right), R$ is the number of re- gions with radiata pine plantations (Table 1), $E_{i}$ is the rotation age for the $i$-th region, $e_{i j}$ is the $j$-th age class for the $i$-th region expressed in years, $e_{i j}=1, \ldots, E_{i}, d_{i j}$ is the wood basic density for the $j$-th age class in the $i$-th region $\left(\mathrm{kgm}^{-3}\right)$, and $s_{k i j}$ is the surface area for the $j$-th age class of the $i$-th region in the $k$-th year of the projection (ha). 


\section{Model variables}

The biomass residue left in the field after harvesting of forest stands included branches and the non-commercial section of the crown. Field activities consisted of mechanized harvesting with an excavator-based harvester. Harvest residues were piled, chipped, and loaded onto trucks for transport to a final destination. Residue estimates were determined with a conversion factor with a mean value of 0.25 tons of residue per ton of harvested stemwood biomass (Ruminot, 2009). Due to the lack of site-specific information, MAI estimates ranging from 15 to $25 \mathrm{~m}^{3} \mathrm{ha}^{-1}$ year ${ }^{-1}$ were used to estimate plantation growth throughout the country (INFOR, 2007; Sedjo, 1999; Toro and Gessel, 1999). Rotation ages were modeled using a range from 20 to 30 years (Toro and Gessel, 1999). The rotation age is usually determined according to economic criteria; therefore, plantations were harvested before the MAI culmination was reached, which is estimated to be approximately 40 years (Acuña 2001; Santana, 1998; Baldini, 1994). The basic density of wood $\left(d_{i j}\right)$ was determined from the age class and region according to the distribution throughout Chile (Espinosa et al., 2005). The data were divided into three geographic areas: (i) area 1 was the region of Valparaíso to Maule, where $d=0.20614+0.07146 \ln (A)$; (ii) area 2 was the Bio Bio region, where $d=0.18334$ $+0.07462 \ln (A)$ and (iii) area 3 was the regions of Araucanía and Los Lagos, where $d=0.16590+$ $0.08464 \ln (A)$, where $d$ is the wood basic density and $A$ is the age of the stand.

Due to mandatory annual reforestation of the harvested area, a reforestation rate was incorporated into the model. The annual average rate of forestation and reforestation reached 60,000 ha in the last 20 years (INFOR, 2007). For this study, forestation at an annual rate of 15,000 to 30,000 ha was considered as a proportion of the surface area planted in each region for 2006 (Equation 2). By this procedure, each region maintained the same proportional representation of plantations through the period of analysis (2010 to 2030), therefore:

$$
f_{k i}=f_{k} \frac{s_{i}}{s}
$$

where $f_{k i}$ is the forested area for the $k$-th year of the projection in the $i$-th region (ha), $f_{k}$ is the total forested area for the $k$-th year (ha), $s_{i}$ is the total area of radiata pine plantations for the $i$-th region in 2006 (ha), and $s$ is the total surface area of radiata pine plantations for all of the regions in 2006 (ha).

The area planted by age class for each year was projected by transforming the values in Table 1 to an annual basis, assuming a homogeneous age distribution of the plantations within 5 years of each age class. Each year, plantations reaching the rotation age were harvested, and their biomass was added to the previous plantation. The next year, the area of the harvested plantations was reforested, starting a new cycle (Equation 3):

$$
s_{k i j}=s_{(k-1) i j}+f_{k i}-c_{(k-1) j}
$$

where $s_{k i j}$ is the planted area for the $j$-th age class for the $i$-th region at the $k$-th year of the projection (ha), $s_{(\mathrm{k}-1) \mathrm{jj}}$ is the planted area for the $j$-th age class for the $i$-th region at the $(k-1)$-th year of the projection (ha), and $s_{(k-1) i j}=0$ when $j=1 . f_{k i}$ is the reforested area at the $k$-th year of the projection for the $i$-th region (ha) and $f_{k i}$ $=0$ when $k=1 ; 1<j<E_{i}, c_{(k-1) j}$ is the harvested surface area at the $(k-1)$-th year of the projection (ha) and $c_{(k-1) j}=0$ when $k=1$.

The total biomass was estimated using the total forested area as established in Equation (1).

\section{Electricity generation and bioethanol production}

Harvested biomass (commercial stemwood biomass) and residues were transformed into electric energy. The energetic efficiency of an electric plant was estimated with variation of 25 to $45 \%$, which depends on the humidity of the biomass (EIA, 2001). A conversion factor of 19.19 GJ per dry ton of biomass was used in all of the calculations (Hall, 1997). In order to estimate the theoretical yields of bioethanol from sugars, the National Renewable Energy Laboratory (NREL, 2009) conversion factors were used. 
Conversion allows prediction of the theoretical yield of bioethanol (the reference value depends on the raw material and the acid hydrolysis process considered) that is feasibly obtained from the proportion of glucose, xylose, mannose, galactose and arabinose in the anhydrous state. The average value of 275 liters of bioethanol per dry ton of biomass was used (Berrocal, 2003).

\section{Incorporation of uncertainty into the model}

The uncertainty in the estimation of the energetic potential of the radiata pine plantations was incorporated. The model used probability distribution functions to represent the uncertainty in the estimations of the harvest residues, MAI, rotation age, and annual forestation rate, assuming that the values for each parameter were normally distributed. The Crystal Ball program (Oracle Corp., Redwood Shores, California, USA), which used the Monte Carlo simulation with Latin Hypercube sampling (Cullen and Frey, 1999; Vose, 1996; Morgan and Henrion, 1990), was used to simulate the uncertainty. The results generated by the model are the probability distributions of electricity and bioethanol generation for the scenarios considered in the study.

\section{Sample size}

The mean and variance of the potential energy generation were determined after 1,500 model simulations. The number of runs was determined following a two-stage process described by Gottfried (1984). The first stage consisted of a preliminary run of 100 iterations to estimate the mean and the standard deviation. In the second stage, the obtained values were used to estimate the number of simulations required to achieve the desired level of confidence according to a $t$ distribution (Equation 4):

$$
n=\left(\frac{t s}{x Y}\right)^{2}
$$

where $n$ is the number of required observations, $t$ is the desired level of confidence (0.05), $s$ is the standard deviation for the potential electricity generated in the runs of step 1, $x$ is the desired range of the mean proportion, and $Y$ is the mean of the estimated potential electricity generated in the runs from step 1.

\section{Results}

Availability of stem biomass and harvest residue

If harvesting residues are considered for a rotation age of between 20 and 30 years, a total of 9.2 million tons would be obtained by 2010 and 28.0 million tons by 2030 . If stem biomass is considered, an additional 45.8 to 140.1 million tons of biomass would be produced for 2010 and 2030, respectively (Table 2). For this estimation, the biomass obtained by common intermediate stand management treatments (thinning and pruning) of radiata pine plantations was not considered.

Table 2. Biomass, electricity and bioethanol produced from residues and bolewood of Pinus radiata plantations in Chile.

\begin{tabular}{|c|c|c|c|}
\hline \multirow[b]{2}{*}{ Variables } & \multicolumn{3}{|c|}{ Year } \\
\hline & 2008 & 2010 & 2030 \\
\hline \multicolumn{4}{|l|}{ Biomass, tx 1000} \\
\hline Residues & $6,129.76$ & $9,156.45$ & $28,025.02$ \\
\hline Residues + bolewood & $30,648.78$ & $45,782.24$ & $140,125.07$ \\
\hline \multicolumn{4}{|l|}{ Electricity $^{1}, \%$} \\
\hline Residues & 16.67 & 24.90 & 76.22 \\
\hline Residues + bolewood & 83.36 & 124.52 & 381.12 \\
\hline \multicolumn{4}{|l|}{ Bioethanol $2 \%{ }^{2}, \%$} \\
\hline Residues & 25.54 & 38.15 & 167.71 \\
\hline Residues + bolewood & 127.70 & 190.76 & 583.85 \\
\hline \multicolumn{4}{|l|}{ Bioethanol $5 \%{ }^{2}, \%$} \\
\hline Residues & 10.21 & 15.26 & 46.71 \\
\hline Residues + bolewood & 51.08 & 76.30 & 233.54 \\
\hline $\begin{array}{l}{ }^{1} \text { Values in percent } \\
\text { Oficial, 2008a). } \\
{ }^{2} \text { Values in percent ac } \\
2008 \text { b). }\end{array}$ & $\begin{array}{l}\text { ording to } \\
\text { ding to D.S }\end{array}$ & ey $N^{\circ} 20$ & Oficial, \\
\hline
\end{tabular}




\section{Electricity and bioethanol produced}

Harvesting residues would generate 73.42 PJ $(20 \%)$ of electricity and stem biomass would produce 293.67 PJ (80\%) of electricity for 2010 . By 2030, these values reached 224.71 (20\%) PJ and $898.83(80 \%) \mathrm{PJ}$, respectively, in the simulation (Figure 1).

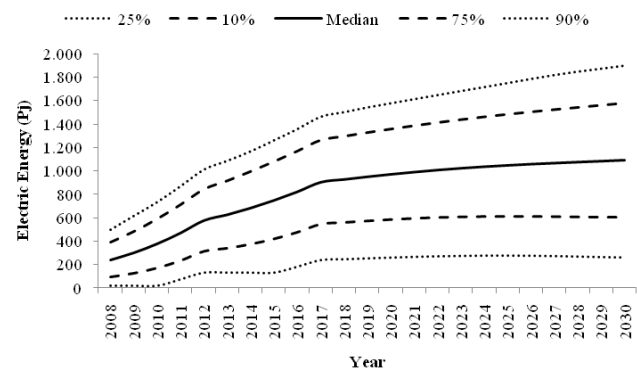

Figure 1. Median predicted annual energy potentially generated from Pinus radiata plantations in Chile (solid line) projected until year 2030. The percentile bands represent the influence of uncertainty in the parameter values (dashed lines $=25$ and 50 percentiles of the predicted values; dotted lines $=5$ and 95 percentiles of the predicted values).

With regard to the production of bioethanol, harvest residues would produce $2.5 \times 10^{6} \mathrm{~L}$ and stem biomass $10.1 \times 10^{6} \mathrm{~L}$ of bioethanol by 2010 . At the end of the simulation period (2030), the production levels reached $7.7 \times 10^{6} \mathrm{~L}$ and $30.8 \times$ $10^{6} \mathrm{~L}$, respectively (Figure 2).

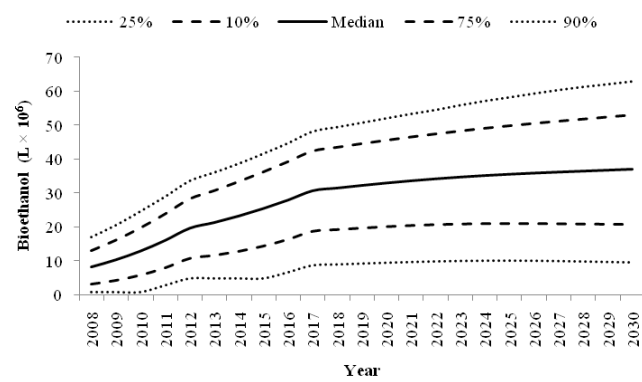

Figure 2. Median predicted annual bioethanol generated from Pinus radiata plantations in Chile (solid line) projected until year 2030. The percentile bands represent the influence of uncertainty in the parameter values (dashed lines $=$ 25 and 50 percentiles of the predicted values; dotted lines $=$ 5 and 95 percentiles of the predicted values).

\section{Projected plantation surface areas}

For the period of the analysis, according to the results of our model radiata pine plantations increased an average of 398,717 ha (27.7\%). This estimate varies between 280,902 and 508,965 ha. The total planted area by 2030 reached between 1.72 and 1.95 million ha (Figure 3).

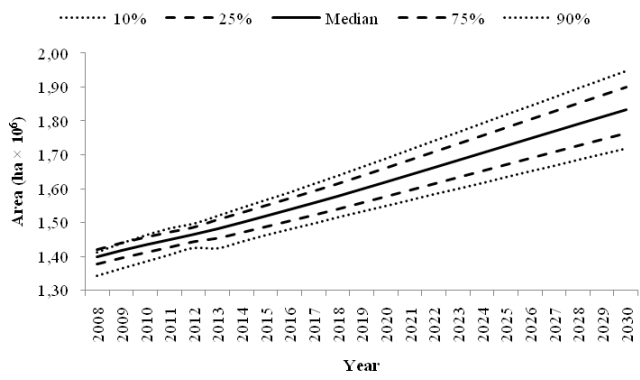

Figure 3. Projected annual areas for Pinus radiata plantations in Chile (solid line). The percentile bands represent the influence of uncertainty in the parameter values (dashed lines $=25$ and 50 percentiles of the predicted values; dotted lines $=5$ and 95 percentiles of the predicted values).

\section{Discussion}

In order to estimate the probability distribution of stemwood biomass and harvesting residue of radiata pine plantations in Chile, the Monte Carlo simulation and functions of probability density were used. Different studies have used Monte Carlo simulations and probability functions to analyze the uncertainty of estimates (Espinosa et al., 2005; Rasinmäki and Melkas, 2005; Smith and Heath, 2001, 2000; Heath and Smith, 2000).

Our model estimates that the potential biomass generation from the harvest of logging residues and stemwood of radiata pine plantations would cover $83.4 \%$ of the installed capacity of electric energy of the Central Interconnected System (CIS), which increased to 294.8 PJ in 2008 (CNE, 2009), and would reach 1100 PJ by 2030 (381\%) considering the expansion of the existing plantations but excluding the high- 
est requirements of population growth and industrialization of the country. However, these amounts might vary according to the size of the electric generation plant because this relates to the efficiency of the conversion process (EIA, 2001).

If only harvesting residues are considered, $16.7 \%$ in 2008 and $76.2 \%$ by 2030 of the energy demand of the SIC would be supplied (Table 2). Likewise, it could totally supply the requirements established in Law 20.257 (Diario Oficial, 2008a), which requires electrical companies to produce $5 \%$ of their energy from nonconventional renewable sources between 2010 and 2014 and increases at an annual rate of $0.5 \%$ from 2015 to reach $10 \%$ "green energy" for the total commercialized energy by 2024 (Diario Oficial, 2008a).

In terms of bioethanol, the Chilean Ministry of Economics has established specifications for commercialization, indicating that mixtures of $2 \%$ to $5 \%$ with car gasoline would be allowed (Diario Oficial, 2008b). Therefore a total of $66,000 \mathrm{~L}$ ( $2 \%$ mixture) and $165,000 \mathrm{~L}(5 \%$ mixture) would be required for the 3,300 million liters of gasoline consumption projected for Chile in 2010 (ODEPA, 2007). According to the model, biomass from harvesting residues might supply $38 \%$ (2\% mixture) or $15 \%$ (5\% mixture) of gasoline with bioethanol by 2010 . If stem biomass is also considered, these values increase to $190 \%$ ( $2 \%$ mixture) and $76 \%$ (5\% mixture) (Table 2).

Projections from the model include an average expansion of the planted surface area of radiata pine plantations of 1.48 million ha in 2010 to 1.83 million ha by 2030 (an increase of $27.7 \%$ ). This surface represents approximately $20 \%$ of the potential surface for forestation of the plantation area with this species in Chile, which includes eroded and marginal lands for sustainable agriculture and livestock crops (information estimated by the authors).

Biomass residues may be increased if we consider biomass produced by radiata pine planta- tion management (i.e., pruning and thinning), which may account for $20 \%$ of the biomass of the final harvest (Ruminot, 2009). In addition, biomass from the Eucalyptus genus (E. globulus and $E$. nitens), which covered an area of 585,000 ha in 2007 and had an annual cut rate of around 18,000 ha (INFOR, 2007), may be a significant additional source for biomass production.

Forest biomass as a source of raw material for energy is renewable and environmentally sustainable. In addition, it may be cultivated on land with irregular topography and sites that may be eroded or susceptible to erosion, with low levels of productivity without compromising the land for food crops. Chile should work towards being self-sufficient by generating nonconventional renewable energy using biomass from plantations that are sustainably managed. This strategy will have low or no impact on food production and positive environmental effects, such as reductions in erosion and facilitation of carbon sequestration.

Forest biomass is a product that could be commercialized either by the forest industries or the energy industry depending on the major source of demand. Moreover, energy from forest biomass may be a convenient alternative for the forest industry because it has better price stability in comparison to pulp.

In conclusion, we determined that stem biomass and harvest residues from radiata pine are potentially an important source for generation of electric energy and bioethanol in Chile. Considering only harvest residues, these plantations were projected to supply $25 \%$ of the electric energy requirements established by Law 20.257 and part (38\%) of the requirements for the mixture of car gasoline with $2 \%$ bioethanol in 2010 .

Further studies are required to quantify the biomass originated from radiata pine silvicultural management and its contribution to the generation of bioenergy. Eucalyptus plantations would represent an additional potential to bioenergy production in Chile. 


\title{
Resumen
}

\begin{abstract}
E. Acuña, M. Espinosa, J. Cancino, R. Rubilar y F. Muñoz. 2010. Estimación del potencial bioenergético de las plantaciones de Pinus radiata, en Chile. Cien. Inv. Agr. 37(1):93102. Se estimó el potencial bioenergético para la producción de electricidad y bioetanol de las plantaciones de Pinus radiata D. Don en Chile, usando como base datos la superficie de plantaciones por clase de edad y región administrativa. Mediante ecuaciones de densidad de la madera por clase de edad y región, contenido de humedad de la madera y eficiencia de una hipotética planta generadora de energía eléctrica, se estimó la electricidad producida por la biomasa a la edad de cosecha incluyendo los residuos de ésta. La producción de bioetanol fue estimada en $275 \mathrm{~L}$ por tonelada seca. El análisis de incertidumbre de la producción de bioenergía se obtuvo mediante funciones de densidad de probabilidades y un supuesto de 1,83 millones de ha de plantaciones de $P$. radiata al año 2030. Los parámetros empleados incluyen la edad de rotación, incremento medio anual, tasa de plantación anual, producción de residuos según edad de rotación y eficiencia de la planta eléctrica. Las simulaciones fueron realizadas para un horizonte de 20 años (2010-2030). El modelo seguido estima que el potencial de generación de biomasa de los residuos de cosecha forestal y de la madera fustal de las plantaciones de P. radiata, podría cubrir el $83,4 \%$ de la capacidad instalada de energía eléctrica del Sistema Interconectado Central (SIC), que asciende a 294,8 PJ el año 2008 y casi cuadriplica (381\%) al año 2030. Según el modelo, la biomasa de residuos podría suplir el $25 \%$ o el $15 \%$ de la mezcla de un 2 y $5 \%$ de gasolina con bioetanol, respectivamente, para el 2010. Si se considera además la biomasa fustal estos valores ascienden a 190 y $76 \%$, respectivamente.
\end{abstract}

Palabras clave: Bioenergía, bioetanol, biomasa, residuos de cosecha, simulación de Monte Carlo.

\section{References}

Acuña, E. 2001. Evaluación del rendimiento económico de regímenes silviculturales de pino radiata, basado en análisis de riesgo. Tesis de Magíster en Ciencias Económicas y Administrativas, Universidad de Concepción. Concepción, Chile. 81 pp.

Baldini, J. 1994. Análisis del crecimiento de un rodal adulto de Pinus radiata D. Don. Memoria de Título, Facultad de Ciencias Forestales, Universidad de Concepción. Concepción, Chile. 93 pp.

Berrocal, A. 2003. Cuantificación y caracterización química de material lignocelulósico de Pinus radiata D.Don en la VIII Región, para la producción de bioetanol. Tesis de Magíster en Ciencias Forestales, Universidad de Concepción. Concepción, Chile. 91 pp.

Chaturvedia, P. 2004. Biomass-The fuel of the rural poor in developing countries. Pages 161-181 In: Sims, R. (ed.). Bioenergy Options for a Cleaner Environment: in Developed and Developing Countries. Elsevier Science. Amsterdam, The Netherlands. 198 pp.
CEC. 2001. Costs and benefits of a biomass-to-ethanol production industry in California. California Energy Commission (CEC). Report. P500-01002. Sacramento, California, USA. 197 pp.

CNE. 2009. Generación bruta SIC-SING. Comisión Nacional de Energía (CNE). Available online at: www.cne.cl/cnewww/export/ sites/default/06_Estadisticas/Documentos/ generacion_bruta_sic_sing.xls (Website accessed: October, 2009).

Cook, J., and J. Beyea. 2000. Bioenergy in the United States: Progress and possibilities. Biomass and Bioenergy 18:441-455.

Cullen, A.C., and H.C. Frey. 1999. Probabilistic techniques in exposure assessment. Plenum Press, NY, USA. 352 pp.

Diario Oficial. 2008a. Ley $N^{\circ} 20.257$. Diario Oficial de la República de Chile. 01 de abril de 2008. Santiago, Chile.

Diario Oficial. 2008b. Decreto Supremo N 11. 2008. Diario Oficial de la República de Chile. 09 de mayo de 2008. Santiago, Chile.

EIA. 2001. Annual energy outlook 2001: With projections to 2020. Energy Information Adminis- 
tration (EIA), US Department of Energy. Washington DC, USA. 262 pp.

Espinosa, M., E. Acuña, J. Cancino, F. Muñoz and D. Perry. 2005. Carbon sink potential of radiata pine plantations in Chile. Forestry 78:11-19.

Gan, J. and C.T. Smith. 2006. Availability of logging residues and potential for electricity production and carbon displacement in the USA. Biomass and Bioenergy 30:1011-1020.

Giampietro, M., S. Ulgiati, and D. Pimentel. 1997. Feasibility of largescale biofuel production. Bioscience 47:587-600.

Gottfried, B.S. 1984. Elements of Stochastic Process Simulation. Prentice-Hall, New Jersey, USA. $304 \mathrm{pp}$.

Graf, A. and T. Koehler. 2000. Oregon cellulose-ethanol study. An evaluation of the potential for ethanol production in Oregon using cellulose-based feedstocks. Report prepared by the Oregon Office of Energy. Portland, Oregon, USA. 30 pp.

Hall, D.O. 1997. Biomass energy in industrialized countries. A view of the future. Forest Ecology and Management 91:17-45.

Hamelinck, C.N., G. van Hooijdonk, and A.P. Faaij. 2005. Ethanol from lignocellulosic biomass: Techno-economic performance in short, middle, and long term. Biomass and Bioenergy 28:384410.

Heath, L.S., and J.E. Smith. 2000. An assessment of uncertainty in forest carbon budget projections. Environmental Science and Policy 3:73-82.

INFOR. 2007. Estadísticas forestales chilenas 2006. Boletín Estadístico 117. Instituto Forestal (INFOR), Ministerio de Agricultura. Santiago, Chile. 163 pp.

Jun, E., W. Kim, and S.H. Chang. 2009. The analysis of security cost for different energy sources. Applied Energy 86:1894-1901.

Morgan, M.G., and M. Henrion. 1990. Uncertainty: a guide to the treatment of uncertainty in quantitative policy and risk analysis. Cambridge University Press, NY, USA. 344 pp.

NREL. 2006. Power Technologies Energy Data Book. $4^{\text {th }}$ Edition. National Renewable Energy Laboratory. Technical Report NREL/TP-62039728. Golden, Colorado, USA. 231 pp.

NREL. 2009. National Renewable Energy Laboratory (NREL). www.eere.energy.gov/biomass/ ethanol_yield_calculator.html (Accessed: March, 2009).

ODEPA. 2007. Informe Final (Versión Preliminar): Comité Público-Privado de Bioenergía. Oficina de Estudios y Políticas Agrarias (ODEPA), Ministerio de Agricultura, Departamento de Políticas Agrarias, Unidad de Bioenergía. Available online at: www.bcn.cl/carpeta_temas/temas_ portada.2007-01-26.2084740943/otros-documentos.../Comite_Bioenergia-Informe_Final.pdf (Website accessed: March, 2009).

Perlack, R.D., L.L. Wright, A.F. Turhollow, and R.L. Graham. 2005. Biomass as feedstock for a bioenergy and bioproducts industry: The technical feasibility of a billion-ton annual supply. Rept. DOE/GO102005-2135. U.S. Dept. of Energy, Oak Ridge, Tennessee, USA. 78 pp.

Rasinmäki, J., and T. Melkas. 2005. A method for estimating tree composition and volume using harvester data. Scandinavian Journal of Forest Research 20:85-95.

Ruminot, J. 2009. Modelo Recuperación de Residuos de Cosecha Forestal de Pinus radiata D. Don, y su Potencial Energético. Memoria de Título, Facultad de Ciencias Forestales, Universidad de Concepción. Concepción, Chile. 134 pp.

Santana, J. 1998. Análisis del crecimiento de un rodal de Pinus radiata D. Don de 42 años de edad. Memoria de Título, Facultad de Ciencias Forestales, Universidad de Concepción. Concepción, Chile. $36 \mathrm{pp}$.

Sedjo, R.A. 1999. The potential of high-yield plantation forestry for meeting timber needs. New Forests 17:339-360.

Seiffert, M., M. Kaltschmitt, and J.A. Miranda. 2009. The biomethane potential in Chile. Biomass and Bioenergy 33:564-572.

Smith, J.E. and L.S. Heath. 2000. Considerations for interpreting probabilistic estimates of uncertainty of forest carbon. Pages 102-111. In: L.A. Joyce, and R. Birdsey (eds.). The impact of climate change on America's Forests. USDA Forest Service, General Technical Report RMRS-GTR-59.

Smith, J.E. and L.S. Heath. 2001. Identifying influences on model uncertainty: an application using a forest carbon budget model. Environmental Management 27:253-267.

Smeets, E.M.W., A.P.C. Faaij, I.M. Lewandowski, and W.C. Turkenburg. 2007. A bottom-up assessment and review of global bio-energy potentials to 2050. Progress in Energy and Combustion Science 33:56-106.

Solomon, B.D., J.R. Barnes, and K.E. Halvorsen. 2007. Grain and cellulosic ethanol: History, economies, and energy policy. Biomass and Bioenergy 31:416-425. 
Toro, J., and S. Gessel. 1999. Radiata pine plantations in Chile. New Forests 18:33-44.

USDE. 2006. Breaking the biological barriers to cellulosic ethanol: A joint research agenda. United State Department. of Energy (USDE). Report DOE/SC-0095. Office of Science and Office of
Energy Efficiency and Renewable Energy. Rockville, Maryland, USA. 206 pp.

Vose, D. 1996. Quantitative Risk Analysis: a Guide to Monte Carlo Simulation Modeling. John Wiley and Sons. Chichester, England. 340 pp. 